\title{
NICOLAU SEVCENKO, MACHADIANO
}

\section{NICOLAU SEVCENKO, MACHADEAN}

\section{JOHN GLEDSON}

University of Liverpool

Liverpool, Reino Unido

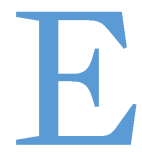

ncontrei Nicolau pela primeira vez nos anos 80, em 1983 ou 84. Antonio Dimas me recomendara a leitura de Literatura como missão, que então fazia um merecido furor no Brasil. Fiquei tão cativado que decidi ir para Londres ouvi-lo. Fomos juntos, eu e David Treece, e ficamos conversando depois. "Vocês precisam conhecer minha mulher", disse ele, e desde então, quando vinha a São Paulo, ficava na casa dele e da Cristina, no Belenzinho. Eles vieram nos visitar em Liverpool duas ou três vezes, e nós descíamos de Liverpool a Londres para vê-los, nas suas visitas anuais. É difícil acreditar que este amigo vivaz, sempre estimulante, e muito brilhante, não está mais conosco.

Quando me pediram para escrever sobre Nicolau como machadiano, me dei conta de que, embora Machado de Assis não fosse seu assunto mais óbvio, ocupou, em certos momentos, um lugar central no seu pensamento. É impossível abstrair meus próprios escritos deste processo - um dos três textos de que vou tratar é um prefácio a um livro meu - mas a influência, claro, foi mútua. Se ele gostava das minhas descobertas de significados alegóricos nos romances machadianos, e até levou-os a outro nível, como veremos, eu dependia, e dependo, muito da sua capacidade de ver e descrever o conteúdo e o contexto sociais e políticos da literatura e da cultura, sobretudo nos primeiros anos da República. Nicolau, embora treinado como historiador, tinha uma crença profunda na importância da literatura, como aliás das artes todas. Seus interesses eram onívoros, como testemunhavam as prateleiras pejadíssimas da casa do Belenzinho.

A primeira vez que Machado desempenha um papel importante na obra de Nicolau é o ensaio final, "A capital irradiante: técnica, ritmos e ritos do Rio", do terceiro volume da História da vida privada no Brasil, volume que ele também editou. Como em Literatura como missão, que contrapõe e compara Lima Barreto e Euclides da Cunha, há dois protagonistas 
contrastantes, Machado e João do Rio. Como diz, com a sua capacidade de resumir verdades complexas com clareza e perspicácia: "A ironia cortante afina o diapasão crítico dos dois num arco tenso mas firme." Todos os seus exemplos machadianos são de "A Semana" - isto é, da década de 1890. Até onde eu sei, ninguém tentara usá-las e interpretá-las como Nicolau, como comentários a coisas e acontecimentos aparentemente triviais, mas de significado histórico profundo. Nessa época - o livro é de 1998 - o interesse nas crônicas apenas começava. Exemplo inesquecível é o primeiro do ensaio, sua interpretação da cena num bonde (da crônica de 21 de janeiro de 1894) na qual o cocheiro tranquilamente assevera que ele pode fumar seu cigarro nos arrabaldes, embora não no centro da cidade: "Vérité en deçà, erreur au delà", como comenta Machado, com uma citação predileta das Lettres provinciales de Pascal. Focalizando a história das "coisas" - o bonde, o cigarro, os próprios arrabaldes - Nicolau "desempacota" Machado, e revela uma sociedade em constante mutação, às vezes sutil, às vezes rápida como a própria eletricidade.

Em 2003, Nicolau generosamente ofereceu-se para escrever um ensaio introdutório para a segunda edição do meu livro Machado de Assis: Ficção e História: "A ficção capciosa e a história traída". Novamente, aparecem as crônicas: mas, caracteristicamente, Nicolau está de olho em limites mais ousados, focalizando os "instantes fugazes", presentes em Quincas Borba (o enforcamento do escravo), em Casa velha (o velho Gira, o escravo enlouquecido), e Esaú e Jacó (a cabocla do Morro do Castelo), que apontam para o papel da escravidão e dos afro-brasileiros na sociedade, assunto que Machado supostamente evitava. Como diz Nicolau no final do prefácio, ele foi um exímio traidor.

No mesmo ano, 2003, a Companhia das Letras publicou uma nova edição de Literatura como missão, lindamente ilustrada (graças sobretudo à Cristina), à qual Nicolau juntou um posfácio: "O núcleo notável e a 'linha evolutiva' da sociedade e cultura brasileiras". Lembro-me de lê-lo com emoção, até mesmo com certo choque. A sua primeira frase é simplesmente "Machado de Assis". Começa por uma análise de "Evolução", história publicada em 1884 na Gazeta de Notícias, mas que esperou até 1895 para ser publicada em livro (em Várias histórias). Sempre fora um dos meus contos preferidos, mas não vira a metade das coisas que Nicolau vê, e de cuja presença real ele nos persuade. Como diz, é uma história simples, "dando mais a impressão de ser uma mera anedota longa". Seu argumento 
fundamenta-se novamente numa dupla contrastante: Bento, fazendeiro que é a encarnação do "medalhão" (até tem a idade certa, 45 anos), e Inácio, homem de negócios empenhado no financiamento de estradas de ferro, e cuja "bonita" frase - "o Brasil é uma criança que está engatinhando; só começará a andar quando tiver muitas estradas de ferro" - seu amigo pouco a pouco rouba, atribuindo-a a si mesmo. A diferença é que ambos são criações, criaturas de Machado, que viu não só os contrastes mas também as ligações profundas entre os dois. Podem parecer - são, até certo ponto - opostos: Bento, superficial e preso às convenções e às frases, Inácio empreendedor e modernizante. Mas, como mostra Nicolau, não são só amigos: pertencem à mesma "igreja". Isto aparece mais nitidamente nos seus nomes, como ele explica numa nota genial: Bento, como S. Bento na igreja católica, representa a tradição, Inácio, como Inácio de Loiola, é a igreja militante, adaptando-se ao mundo moderno - para melhor preservar a igreja. Há, pois, debaixo das diferenças, uma unidade fundamental, que Machado soube captar, até mesmo cinco anos antes da chegada da República, que inaugurou a sua plena floração. Noutras palavras, o nó da sociedade corrupta e excludente, analisada em Literatura como missão, já se encontra, ou se profetiza, em Machado. O prazer da descoberta destes significados alegóricos reside, aqui como nunca, na descoberta da sutileza e da abrangência - ia dizer da isenção - do pensamento histórico machadiano. Este, para mim, é um dos melhores e mais surpreendentes ensaios escritos no que vai deste século sobre Machado - para comparar com ele, só me ocorre o "Machado maxixe", de José Miguel Wisnik, também centrado num conto.

Não basta dizer que Nicolau foi um machadiano "bissexto" ou ocasional. Este ensaio-posfácio mostra que Machado era, ou veio a ser, central para ele. Mostra também como as intuições presentes na obra do "maior autor brasileiro" podem ainda inspirar, quando lidas com espírito aberto e criativo. Há poucas pessoas que merecem estes adjetivos tanto quanto Nicolau.

Recebido: 7.10 .14 